Przegląd Badań Edukacyjnych Educational Studies Review

ISSN 1895-4308

nr 21 (2/2015), s. 61-80

Dagna Dejna

Uniwersytet Mikołaja Kopernika, e-mail: dagnadejna@umk.pl

Filip Nalaskowski

Uniwersytet Mikołaja Kopernika, e-mail: filipn@umk.pl
ORYGINALNE

ARTYKULY

BADAWCZE

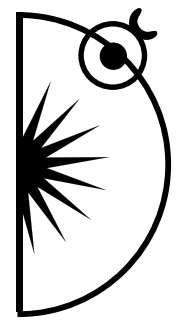

\title{
Background przyszłych pedagogów. Na podstawie badań nad młodzieżą planującą podjąć studia pedagogiczne oraz badań nad studentami kończącymi pedagogikę
}

http://dx.doi.org/10.12775/PBE.2015.048

\section{The Background of Future Teachers. Based on Study on the Youth Planning to Study Pedagogy and Pedagogy Students}

\footnotetext{
Abstract

The aim of the study is to present widely understood sources in reaching pedagogy - as a field of study. Describing a background of future teachers.

The collected data set allows to formulate answers to the questions: Who are future teachers? Where do they come from? What kind of family background do they have? Why do they want to study/ study pedagogy? What are their aims in studying education? What level of capitals (social, economic and cultural) has a youth who plan to study pedagogy?

The data presented in this text are derived from two sources and were collected over the past few years. The first source is a research project entitled: Study of educational plans of youth in Grudziadz and surrounding areas.

We reached $72 \%$ (2,025 of 2,800) of all senior, and pre-senior classes students in Grudziądz and region (within a radius of $30 \mathrm{~km}$, Świecie, Nowe, Łasin).

The second source of data is own prepared nationwide survey of students of pedagogy. The study involved 246 third-year students of pedagogy, stationary mode, in three academic cen-
} 
ters in Poland. In each place analyzes were conducted both in the public and private university.

First, it will be presented a set of a data illustrating the declarations of high school graduates who plan to study pedagogy. In addition, their plans, aspirations, motivations, level of symbolic capital and the origin factors will be described. Prospective teachers (those who declare their willingness to undertake educational studies) will be portrayed in a comparison to the other high school graduates.

The second task 'the study on students' is closely related the previous one. The pointed in a title 'background' of respondents, so their origin, family situations, the results of baccalaureate, aspirations and their path to the pedagogy.

The data selected in this manner are the bases to build a generalized conclusions on the situation of future teachers, their origin and sources of interest in pedagogy.

Key words: educational potential, symbolic capital, social experience, higher education, research, educators, youth, studies

\section{Wprowadzenie}

Celem opracowania jest zaprezentowanie szeroko rozumianych źródeł dochodzenia do pedagogiki - jako kierunku studiów. Zrelacjonowany zostanie background przyszłych pedagogów.

Zebrany zestaw danych pozwala sformułować odpowiedzi na pytania: jacy są przyszli pedagodzy? Skąd pochodzą? Z jakich rodzin? Po co chcą studiować/ /studiują pedagogikę? Jakie są ich motywacje do podjęcia studiów pedagogicznych? Jakim poziomem kapitałów: społecznego, ekonomicznego i kulturowego odznacza się młodzież planująca studiować pedagogikę? Czy przyszli pedagodzy są sprawczy?

Dane prezentowane w tym tekście pochodzą z dwóch źródeł i były zbierane na przestrzeni kilku ostatnich lat. Pierwsze źródło stanowi projekt badawczy zatytułowany: „Badanie planów edukacyjnych młodzieży Grudziądza i okolic”. Projekt ów realizowany był przez zespół naukowy (www.accept.umk.pl, dostęp: 5.5.2015), którego członkami są autorzy tego tekstu. Dalej, dla ułatwienie, badania te nazywane będą Badaniami grudziądzkimi. W przedsięwzięciu udział wzięło 2025 uczniów. To oznacza, że dotarliśmy do (2025 z 2800) wszystkich uczniów klas maturalnych i przedmaturalnych szkół Grudziądza i regionu (w promieniu $30 \mathrm{~km}$; Świecie, Nowe, Łasin).

Drugim źródłem danych jest autorskie ogólnopolskie badanie nad studentami pedagogiki. Badaniu poddano 246 studentów III roku pedagogiki w trybie stacjonarnym, w trzech ośrodkach akademickich w Polsce. W każdym ośrodku 
analizy prowadzone były zarówno w uczelni publicznej, jak i niepublicznej. Przedsięwzięcie to nazwane dalej będzie Badaniami nad studentami.

\section{Zadania}

Podczas prac koncepcyjnych nad tekstem założono dwa zadnia do zrealizowania. Pierwsze nawiązuje do Badań grudziqdzkich, drugie zaś do Badań nad studentami. Oba dotyczą szerokiego pojęcia backgroundu przyszłych pedagogów.

Po pierwsze, zaprezentowany zostanie garnitur danych obrazujących deklaracje maturzystów, którzy planują podjąć studia pedagogiczne, wobec tego kierunku studiów. Ponadto zrelacjonowane zostaną ich plany, aspiracje i motywacje, poziom kapitału symbolicznego oraz uwarunkowania związane z pochodzeniem. Przyszli pedagodzy (czyli ci, którzy deklarują chęć podjęcia studiów pedagogicznych) zostaną ukazani na tle pozostałych przebadanych maturzystów.

Po drugie, zadanie wiąże się także z Badaniami nad studentami i ściśle nawiązuje do poprzedniego. Zrelacjonowany zostanie tytułowy background badanych, a więc ich korzenie, pochodzenie, sytuację rodzin, wyniki matur, pewien zakres planów oraz ścieżka dochodzenia do pedagogiki.

W ten sposób wyselekcjonowane dane stanowią podstawę do formułowania uogólnionych wniosków dotyczących kondycji przyszłych pedagogów, ich korzeni oraz źródeł zainteresowania pedagogiką.

\section{Dane: teren badań, populacja, metodologia i narzędzia}

\section{Badania grudziądzkie}

Badania prowadzono w promieniu 30 kilometrów od Grudziądza położonego w woj. kujawsko-pomorskim; w samym Grudziądzu oraz w mniejszych miejscowościach: Świeciu, Nowem i Łasinie. Diagnozą objęto młodzież klas maturalnych i przedmaturalnych. Dla całościowego i wiernego ujęcia badanego zjawiska zdecydowaliśmy się na objęcie badaniem wszystkich uczniów klas maturalnych i przedmaturalnych we wszystkich typach szkół „dziennych”, w których można było uzyskać maturę (oprócz tych dla dorosłych).

Objęcie badaniem wszystkich członków rozpatrywanej populacji pozwoliło nam na unikniecie problemu doboru próby reprezentatywnej. Co więcej, taka strategia w sposób maksymalny przybliża stan faktyczny, a wyniki badań 
stają się bardzo wiarygodne. Jak już wspomniano, badaniu poddano 2025 respondentów.

Celem, który postawiliśmy sobie, przygotowując projekt badań, była charakterystyka uczniów klas maturalnych oraz planów edukacyjnych młodzieży Grudziądza i okolic, ze szczególnym skoncentrowaniem na planach wobec studiów wyższych.

W ścisłym nawiązaniu do celu został sformułowany główny problem badawczy: „Jakie i czym warunkowane są plany edukacyjne młodzieży Grudziądza i okolic?".

W uzupełnieniu do głównego problemu badawczego sformułowano szczegółowe problemy badawcze:

1. Jaka jest ogólna charakterystyka uczniów klas maturalnych w badanym terenie?

2. Czego poszukuje młodzież w odniesieniu do edukacji wyższej?

3. Jaki jest kapitał symboliczny badanych?

4. Co w świetle zebranych danych może mieć szczególne znaczenie dla decyzji edukacyjnych młodzieży?

W badaniu zastosowano autorski kwestionariusz ankiety. Pytania (było ich 19) miały w większości charakter zamknięty. Pytania pierwszej części dotyczyły płci, wieku i miejsca zamieszkania ankietowanych.

Kolejna część kwestionariusza odnosiła się do szeroko pojętych planów edukacyjnych. Kluczowy dla tego tekstu wątek wiązał się z czynnikami decydującymi o wyborze przez badanych uczelni i ośrodka studiów. Ankietowani zastali poproszeni o zaznaczenie, które z wymienionych czynników mają dla nich decydujące, pozytywne, znaczenie. Były to: bliskość domu rodzinnego, oferta kierunków, koszt studiów, prestiż uczelni, możliwości „życia studenckiego", preferencje wśród znajomych i rodziny, duże miasto. Kafeterię ustalono w toku badań pilotażowych, w których to pytanie miało charakter otwarty - najpopularniejsze z poszukiwanych odpowiedzi $(99,7 \%)$ zostały skategoryzowane w postaci siedmiu opcji. Należy tu podkreślić, że w tym pytaniu ankietowani mogli zaznaczyć więcej niż jedną możliwość.

Ostatnim wątkiem odnoszącym się do planów edukacyjnych był zamiar kontynuowania nauki na studiach II stopnia.

Trzecią składową kwestionariusza były pytania służące pomiarowi kapitału symbolicznego zgodnie z koncepcją Pierre'a Bourdieu. Pewnym uzupełnieniem dla całego badania była próba określenia poziomu poczucia własnej sprawczości - pewności swoich możliwości, która charakteryzowała badanych. 


\section{Badania nad studentami}

Rozpoznanie zostało przeprowadzone w trzech ośrodkach akademickich w Polsce: w Warszawie, Poznaniu i Olsztynie. Każdy z ośrodków, które zostały poddane badaniu, musiał spełniać następujące warunki - musiały w nim działać co najmniej dwie uczelnie - publiczna i niepubliczna. Obie powinny prowadzić studia na kierunku pedagogika. Także w przypadku obu studia te powinny odbywać się w trybie stacjonarnym. Wreszcie warunek ostatni - w uczelniach musiało odbywać się kształcenie na III roku studiów. Ostatecznie do badań przystapiło 246 studentów. Dobór próby był doborem losowym (grupowym), ale poprzedzonym doborem celowym, a wielkość próby była statystycznie reprezentatywna dla badanej populacji.

Zależało nam, aby badanie zostało przeprowadzone pod koniec studiów pedagogicznych. W ten sposób mogliśmy nakreślić rzeczywistą sylwetkę absolwenta pedagogiki; uchwycić moment tuż przed podjęciem pracy w zawodzie pedagoga, tuż przed odebraniem dyplomu nadającego status pedagoga. Badaniu zostali poddani wyłącznie studenci studiów dziennych. Zastosowano metodę sondażu diagnostycznego, a wykorzystanym narzędziem był kwestionariusz ankiety.

W części metryczkowej kwestionariusza ankiety zadaliśmy pytania o płeć, wiek, pochodzenie. Kolejna część kwestionariusza dotyczyła rodziny pochodzenia badanych, dzięki temu możliwe było ustalenie ich backgroundu. Pytaliśmy więc o zawód i wykształcenie rodziców, liczbę i wykształcenie rodzeństwa oraz ogólną sytuację materialną rodziny. Kolejna cześć zawierała pytania o aktualną sytuację materialną badanych (miejsce i typ mieszkania, posiadane dobra materialne) oraz charakter wykonywanej pracy zarobkowej. Kolejne części kwestionariusza dostarczały informacji o ścieżce edukacyjnej badanych, wyników matur, motywacji do studiowania pedagogiki, planów i aspiracji rodzinnych oraz zawodowych, oceny macierzystej uczelni i zainteresowań kulturalnych. Właśnie wyniki dociekań dotyczące tego obszaru zostaną zaprezentowane w tym tekście.

Kolejna część kwestionariusza to zadania testowe, których zadaniem była ocena stanu wiedzy i kompetencji przyszłych pedagogów. Test dotyczył wiedzy ogólnej, wiedzy pedagogicznej i kompetencji językowych. Test wiedzy ogólnej składał się z 20 pytań, które podzieliliśmy na części. Pierwsza część dotyczyła bardzo szeroko rozumianej wiedzy o społeczeństwie (z dziedziny historii, kultury, biologii, edukacji i tzw. różne). Po teście wiedzy ogólnej studenci zmierzyli się z pytaniami z zakresu wiedzy pedagogicznej. Ostatni rodzaj testu, 
któremu poddani zostali badani, to test z języka obcego. Z wynikami części testowej można zapoznać się w innych naszych publikacjach (Dejna, Nalaskowski, 2013).

Podstawowym kryterium różnicującym było kryterium rodzaju uczelni: publiczna - niepubliczna. W tym tekście owe różnice nie będą relacjonowane. Kluczowy będzie inny fragment badań, mianowicie tytułowy background wszystkich badanych.

\section{Badania grudziądzkie}

\section{Ogólna charakterystyka grupy młodzieży, która zadeklarowała chęć studiowania pedagogiki}

Jak już zostało wspomniane, przebadana populacja wynosiła 2025 respondentów - uczniów klas maturalnych i przedmaturalnych. Do analiz, które są przedmiotem tego opracowania, przyjęto wszystkich badanych, którzy w sposób wyraźny zadeklarowali chęć studiowania kierunku pedagogicznego. Respondenci mieli możliwość wskazania do trzech kierunków, które biorą pod uwagę. Sugestią było wskazanie ich wg porządku preferencji. Do poniższych analiz przyjęto wszystkich, którzy choć raz, niezależnie od miejsca, podali kierunek pedagogiczny.

Jaką przyjęto definicję kierunku pedagogicznego? W ramach kodowania wyróżniono trzy takie kierunki: pedagogika (zawierająca także pedagogikę specjalną [bardzo niski odsetek wskazań - poniżej $0,05 \%$ ]), pracę socjalną oraz resocjalizację. W sumie do analiz wytypowano N(„P”) = 145 osób.

Przy dokonywaniu analiz zastosowano strategię odnoszenia wyników przyszłych pedagogów do wyników całej populacji poddanej badaniu. Należy w tym miejscu doprecyzować, że za całą populację przyjmujemy wszystkich badanych, którzy zdecydowani są podjąć studia, a nie wszystkich, którzy wzięli udział w badaniu. Naszym zdaniem pozwoli to na jaśniejsze zobrazowanie postaw i deklaracji pedagogów na tle przyszłych studentów w ogóle.

Dla jasności wywodu pojęcia pedagogiki i kierunki pedagogiczne (,,czysta pedagogika" stanowiła dokładnie $80 \%$ wskazań, resocjalizacja $15,6 \%$, a praca socjalna nieco ponad 4,5\%) traktowane będą jako tożsame. 
Dagna Dejna, Filip Nalaskowski Background przyszłych pedagogów. Na podstawie...

Tabela 1. Kierunki pedagogiczne wskazania

\begin{tabular}{|l|c|c|c|c|}
\hline $\begin{array}{c}\text { Liczba wskazań na } \\
\text { pedagogikę }\end{array}$ & Pedagogika & Resocjalizacja & Praca socjalna & Razem \\
\hline Jako 1 wybór & 78 & 12 & 4 & 94 \\
\hline Jako 2 wybór & 46 & 10 & 3 & 59 \\
\hline Jako 3 wybór & 14 & 5 & 1 & 20 \\
\hline
\end{tabular}

Należy na wstępie zauważyć, że obniżające się wartości wskazań są wynikiem pomijania odpowiedzi w kolejnych opcjach. Wszyscy (prawie wszyscy), którzy chcieli studiować, potrafili wskazać „główny” kierunek, ale już tylko część z nich decydowała się na wskazanie drugiego kierunku, a już nieliczni mieli pomysł na trzeci.

Jak widać, najczęściej wskazywana była pedagogika. Najrzadziej praca socjalna. Co ciekawe, resocjalizacja podobnie często była podawana zarówno na pierwszym, jak i drugim miejscu, co oznacza, że bardzo często była tzw. kierunkiem ,awaryjnym”.

\section{Skąd pochodzą przyszli pedagodzy?}

Tabela 2 pokazuje, z jakich szkół średnich rekrutują się przyszli pedagodzy.

Tabela 2. Szkoły średnie pedagogów

\begin{tabular}{|l|c|c|}
\hline \multicolumn{1}{|c|}{ Liczba wskazań na pedagogikę } & Licea & Technika \\
\hline 1 wskazanie & $90,0 \%$ & $10,0 \%$ \\
\hline 2 wskazania & $91,3 \%$ & $8,7 \%$ \\
\hline 3 wskazania & $100,0 \%$ & $0,0 \%$ \\
\hline Razem wśród „pedagogów" & $90,3 \%$ & $9,7 \%$ \\
\hline W całej badanej populacji & $74,7 \%$ & $25,3 \%$ \\
\hline
\end{tabular}

Zestawienie nie przynosi „sensacji”. Zdecydowana większość przyszłych pedagogów rekrutuje się spośród uczniów liceów - niezależnie od determinacji jest to około $90 \%$. Co ciekawe, w całej badanej populacji - wśród osób, które deklarowały podjęcie studiów po maturze, do liceów uczęszczało ,jedynie" niespełna $75 \%$ respondentów, zatem przyszli pedagodzy daleko częściej są absolwentami liceów ogólnokształcących niż reszta studentów. 
Tabela 3 prezentuje, z jakich miejscowości pochodzą przyszli pedagodzy.

Tabela 3. Pedagodzy a kategoria miejscowości pochodzenia - odsetki

\begin{tabular}{|l|c|c|c|c|}
\hline Liczba wskazań na pedagogikę & Pow. 50 tys. & $\begin{array}{c}\text { Od } 10 \text { do } 50 \\
\text { tys. }\end{array}$ & Od 1do 10 tys. & Do 1 tys. \\
\hline 1 wskazanie & $53,3 \%$ & $15,0 \%$ & $11,7 \%$ & $20,0 \%$ \\
\hline 2 wskazania & $60,9 \%$ & $13,0 \%$ & $4,3 \%$ & $21,7 \%$ \\
\hline 3 wskazania & $0,0 \%$ & $50,0 \%$ & $0,0 \%$ & $50,0 \%$ \\
\hline Średnia wśród „pedagogów" & $53,8 \%$ & $15,2 \%$ & $10,3 \%$ & $20,7 \%$ \\
\hline Średnia w całej badanej populacji & $47,1 \%$ & $14,2 \%$ & $14,9 \%$ & $23,9 \%$ \\
\hline
\end{tabular}

Jak widać, kategoria miejscowości pochodzenia nie jest czynnikiem, który znacznie odróżniałby pedagogów od reszty badanej populacji. Zauważyć możemy jedynie delikatne różnice. Przyszli studenci kierunków pedagogicznych nieco częściej pochodzą z miast (powyżej 50 tysięcy mieszkańców) niż reszta badanych zdecydowanych na podjęcie studiów - 53,8\% do 47,1\%. Co ciekawe, względem całości badanych przesunięcie na rzecz miast nastapiło kosztem wsi - 20,7\% wśród pedagogów i 23,9\% w całej populacji zdecydowanej podjąć jakiekolwiek studia.

Także wewnętrznie grupa pedagogów wydaje się dość jednolita, choć widzimy, że mieszkańcy dużych miast wyraźniej dominują w grupie bardziej zdeterminowanych do studiowania pedagogiki.

\section{Motywy determinujące wybór ośrodka studiów}

Warte namysłu wydaje się pytanie: jakie czynniki decydujące o wyborze ośrodka studiów dominują w populacji „P”? Wśród kafeterii możliwości (po uprzednim testowaniu podczas badań pilotażowych) znalazły się następujące odpowiedzi: bliskość ośrodka, koszt studiów, preferencje znajomych, oferta uczelni, prestiż uczelni, chęć studiowania w dużym mieście.

Tabela 4. Czynniki decydujące o wyborze ośrodka studiów - odsetki dla badanych grup

\begin{tabular}{|c|c|c|c|c|c|c|c|}
\hline $\begin{array}{c}\text { Liczb } \\
\text { wskazań na } \\
\text { pedagogikę }\end{array}$ & $\begin{array}{c}\text { bliskość } \\
\text { domu } \\
\text { rodzin- } \\
\text { nego }\end{array}$ & $\begin{array}{c}\text { koszt } \\
\text { studiów }\end{array}$ & $\begin{array}{c}\text { preferencje } \\
\text { wśród } \\
\text { znajomych } \\
\text { i rodziny }\end{array}$ & $\begin{array}{c}\text { możliwości } \\
\text { życia stu- } \\
\text { denckiego }\end{array}$ & $\begin{array}{c}\text { oferta } \\
\text { kierunków }\end{array}$ & $\begin{array}{c}\text { prestiż } \\
\text { uczelni }\end{array}$ & $\begin{array}{c}\text { duże } \\
\text { miasto }\end{array}$ \\
\hline 1 wskazanie & $39,2 \%$ & $73,3 \%$ & $22,5 \%$ & $32,5 \%$ & $71,7 \%$ & $45,0 \%$ & $35,0 \%$ \\
\hline
\end{tabular}


Tabela 4. cd.

\begin{tabular}{|l|c|c|c|c|c|c|c|}
\hline 2 wskazania & $47,8 \%$ & $52,2 \%$ & $13,0 \%$ & $26,1 \%$ & $82,6 \%$ & $43,5 \%$ & $30,4 \%$ \\
\hline 3 wskazania & $100,0 \%$ & $100,0 \%$ & $100,0 \%$ & $0,0 \%$ & $50,0 \%$ & $50,0 \%$ & $0,0 \%$ \\
\hline $\begin{array}{l}\text { Suma wśród } \\
\text { "pedago- } \\
\text { gów” }\end{array}$ & $41,4 \%$ & $70,3 \%$ & $22,1 \%$ & $31,0 \%$ & $73,1 \%$ & $44,8 \%$ & $33,8 \%$ \\
\hline $\begin{array}{l}\text { Średnia } \\
\text { w całej } \\
\text { badanej } \\
\text { populacji }\end{array}$ & $33,8 \%$ & $58,2 \%$ & $20,1 \%$ & $31,1 \%$ & $75,8 \%$ & $51,2 \%$ & $37,3 \%$ \\
\hline
\end{tabular}

Podobnie jak poprzednio, ujawniają nam się dwie tendencje. Pedagodzy kierują się nieco innymi czynnikami przy wyborze ośrodka studiów niż reszta badanych. Także wewnętrznie grupa przyszłych studentów kierunków edukacyjnych nie jest jednorodna - ci bardziej zdeterminowani do studiowania pedagogiki biorą pod uwagę inne względy niż ci mniej przekonani.

Największe różnice między pedagogami a całą populacją badanych widać w trzech kategoriach. Częściej (41-34\%) ma dla nich znaczenie bliskość domu rodzinnego i koszt studiów (70-58\%), za to mniej istotny jest prestiż uczelni (45-51\%). W pozostałych kategoriach, takich jak preferencje znajomych, oferta uczelni, oferta „życia studenckiego" i chęć studiowania w dużym mieście, nie odnotowano znaczących różnic między pedagogami a całością badanej populacji.

Co do zróżnicowania wewnętrznego, to dość wyraźne różnice widzimy w prawie wszystkich kategoriach. Szczególnie mocno istotne dla grupy „zdeterminowanych" były: bliskość domu rodzinnego i oferta studiów, za to mniej ważne: koszt studiów, preferencje znajomych, oferta „życia studenckiego” i chęć studiowania w dużym mieście.

\section{Plany: tryb studiów i studia II stopnia}

Ciekawych danych dostarcza pytanie o preferowany tryb studiów. Spośród badanych $54,5 \%$ przyszłych pedagogów planuje podjąć studia stacjonarne, niestacjonarne - 39,7\%. Dla porównania w całej badanej populacji przyszłych studentów wartości te wynoszą odpowiednio $74,1 \%$ i $21,9 \%$. 
Tabela 5. Preferowany tryb studiów

\begin{tabular}{|l|c|c|c|}
\hline Liczba wskazań na pedagogikę & Stacjonarny & Niestacjonarny & Brak \\
\hline 1 wskazanie & $51,7 \%$ & $43,3 \%$ & $5,0 \%$ \\
\hline 2 wskazania & $65,2 \%$ & $23,9 \%$ & $10,9 \%$ \\
\hline 3 wskazania & $100,0 \%$ & $0,0 \%$ & $0,0 \%$ \\
\hline Razem wśród „pedagogów” & $54,5 \%$ & $39,7 \%$ & $5,9 \%$ \\
\hline W całej badanej populacji & $74,1 \%$ & $21,9 \%$ & $4,1 \%$ \\
\hline
\end{tabular}

Wnioski należy formułować ostrożnie, lecz odnosząc się do akademickich doświadczeń oraz danych z badań nad studentami, można stwierdzić, że pedagodzy rekrutują się spośród grupy, dla której wartości rodzinne są bardzo ważne. Wcześnie zakładają rodziny i podejmują pracę zawodową. Co więcej, niestacjonarne studia pedagogiczne należą do jednych z najtańszych w ofercie kształcenia uniwersyteckiego - co zapewne ma również znaczenie (tę tezę potwierdzają wspomniane motywacje decydujące o wyborze ośrodka studiów dla ponad $70 \%$ przyszłych pedagogów koszt studiów jest decydujący; dla całej populacji wskaźnik ten wynosi 58,2\%).

Przyszłym pedagogom nie jest obca refleksja dotycząca przyszłości.

Tabela 6. Plany wobec studiów II stopnia

\begin{tabular}{|l|c|c|c|}
\hline Liczba wskazań na pedagogikę & Tak & Nie & Nie wiem/brak \\
\hline 1 wskazanie & $60,0 \%$ & $2,5 \%$ & $37,5 \%$ \\
\hline 2 wskazania & $65,2 \%$ & $0,0 \%$ & $34,8 \%$ \\
\hline 3 wskazania & $100,0 \%$ & $0,0 \%$ & $0,0 \%$ \\
\hline Razem wśród „pedagogów" & $61,4 \%$ & $2,1 \%$ & $36,6 \%$ \\
\hline W całej badanej populacji & $53,3 \%$ & $3,7 \%$ & $43,0 \%$ \\
\hline
\end{tabular}

Aż 61,4\% spośród nich zamierza kontynuować naukę na studiach II stopnia, wartość ta dla całej populacji wynosi, dla porównania, tylko 53,3\%. Warty uwagi wydaje się fakt, że pewność co do podjęcia studiów II stopnia wzrasta wraz z poziomem determinacji do studiowania pedagogiki. To oznacza, że osoby odznaczające się wysokim poziomem motywacji do studiowania na kierunkach pedagogicznych (trzy i dwa wskazania) należą do grupy młodzieży bardziej ambitnej - planującej uzyskać tytuł zawodowy magistra. 
Dagna Dejna, Filip Nalaskowski Background przyszłych pedagogów. Na podstawie...

\section{Poczucie sprawstwa}

Podobną zależność widać wyraźnie przy pytaniu o poczucie sprawstwa (Kowalczuk-Walendziak, 2012). Wartość ta mierzona była za pomocą pytania: „Czy poradziłbyś sobie, gdybyś miała za zadanie samodzielnie zorganizować festiwal muzyczny dla 1000 uczestników?".

Tabela 7. Poczucie sprawstwa

\begin{tabular}{|l|c|c|}
\hline \multicolumn{1}{|c|}{ Liczba wskazań na pedagogikę } & Tak & Nie \\
\hline 1 wskazanie & $46,7 \%$ & $53,3 \%$ \\
\hline 2 wskazania & $52,2 \%$ & $47,8 \%$ \\
\hline 3 wskazania & $100,0 \%$ & $0,0 \%$ \\
\hline Razem wśród "pedagogów" & $48,3 \%$ & $51,7 \%$ \\
\hline W całej badanej populacji & $43,8 \%$ & $56,2 \%$ \\
\hline
\end{tabular}

Rozważania na temat poczucia sprawstwa społecznego pedagogów moga mieć istotne znaczenie naukowe i społeczne. Doświadczanie poczucia sprawstwa społecznego przez pedagogów może odgrywać ważną rolę w osiaganiu przez nich różnych celów. Może się przyczyniać do większej skuteczności w realizowaniu obowiązków i zadań związanych z ich rolą, dokonywania zmian w środowisku społeczno-pedagogicznym, pobudzania (wyzwalania) dążenia do zachowań twórczych, innowacyjnych. Z psychologicznego punktu widzenia istnienie poczucia sprawstwa u pedagogów może wywoływać u nich specyficzny sposób autowaloryzacji, lokowanie wymagań związanych z pełnioną funkcją w obszarze własnego Ja czy tworzyć przeświadczenie o sensowności wysiłków (działań) w sferze społecznej, zwłaszcza w obszarze wychowania, opieki, profilaktyki, resocjalizacji, animacji społeczno-kulturalnej, działalności charytatywnej i wolontariackiej (Kowalczuk-Walendziak, 2012).

Z tabeli, w której przedstawiono wyniki, widać, że poziom poczucia sprawstwa u przyszłych pedagogów jest nico niższy niż w pozostałej populacji. Widoczna jest jednak inna, ciekawa i podobna do wcześniejszej zależność. Otóż ponownie poczucie sprawstwa rośnie wprost proporcjonalnie do determinacji do studiowania kierunku pedagogicznego.

\section{Kapitał symboliczny badanych}

Ostatnim wątkiem domykającym tę cześć relacji z badań jest kwesta poziomu kapitału symbolicznego u badanych. Pomysł mierzenia kapitału symboliczne- 
go będącego, wg Pierre'a Bourdieu sumą kapitałów: kulturowego, społecznego i ekonomicznego, był już wielokrotnie wykorzystywany przez uczonych, chcących stawiać diagnozy dotyczące szeroko rozumianej kondycji swoich respondentów. My natomiast zastosowaliśmy nowe, całkowicie autorskie narzędzie pozwalające mierzyć owe wartości.

Pierre Bourdieu nazwał kapitał czynnikiem, który w najbardziej elementarny sposób porządkuje życie społeczne. Wyróżnił trzy zasadnicze formy kapitału: ekonomiczny, kulturowy i społeczny (Trutkowski, Mandes, 2005).

Chcąc w sposób prosty i jasny oszacować poziomy poszczególnych kapitałów, dokonaliśmy ich operacjonalizacji. Co oczywiste, w ramach tak uproszczonego rozpoznania, możliwe jest jedynie przybliżenie wartości poszczególnych kapitałów.

Kapitał ekonomiczny diagnozowany był na podstawie pytań o poziom materialny rodzin, z których pochodzą badani, ale także podejmowane przez nich samych dodatkowo prace zarobkowe.

Za pomocą trzech pytań staraliśmy się ocenić poziom kapitału społecznego. Przyjęliśmy, że dla bardzo prostego jego oszacowania zapytamy o dostęp do specyficznych usług i profesji. Wszystkie pytania były skonstruowane podobnie. Badani byli stawiani w hipotetycznej sytuacji - kłopoty zdrowotne, problemy prawne, kłopoty finansowe - i pytani o to, u kogo szukaliby pomocy. Jeśli odpowiedzi wykazywały, że w kręgu ich znajomych znajdowali się prawnicy, lekarze, osoby skłonne udzielać pożyczek, wówczas badany uzyskiwał maksymalną liczbę punktów. Jeśli badani planowali udać się po pomoc po prostu do znajomych, rodziny, wówczas uzyskiwali mniej punktów. Jeśli nie mieli wśród znajomych osób do których mogliby się udać po pomoc - nie uzyskiwali punktów.

Poziom kapitału kulturowego szacowany był na podstawie aż pięciu pytań. Po pierwsze, pytaliśmy, ile języków obcych badani znają dobrze. Następnie dociekaliśmy, ile mają własnych książek w domowej biblioteczce - gdzie wartością krytyczną było minimum 30 sztuk. W kolejnym elemencie badani byli proszeni o ocenę siebie samych jako uczniów w skali od „zdecydowanie słaby” do „zdecydowanie wyróżniający się”. Następny wątek dotyczył posiadanych formalnych kompetencji. Pytaliśmy, czy badani posiadają prawo jazdy, certyfikaty językowe, uprawnienia zawodowe. Na samym końcu pytaliśmy o osiągnięcia, którymi młodzi ludzie „mogą się pochwalić”. To pytanie miało charakter otwarty. Docenione zostały sukcesy w konkursach, olimpiadach, zawodach, zaangażowanie w ważne przedsięwzięcia pozaszkolne.

W badaniu maksymalne możliwe do uzyskania wyniki to: 10 dla kapitału ekonomicznego i społecznego oraz 11 dla kapitału kulturowego. Jak nie trudno obliczyć, maksymalna wartość dla kapitału symbolicznego wynosiła 31. 
Dagna Dejna, Filip Nalaskowski Background przyszłych pedagogów. Na podstawie...

Tabela 8. Wartości kapitałów w poszczególnych grupach przyszłych pedagogów

\begin{tabular}{|l|c|c|c|c|}
\hline \multicolumn{1}{|c|}{ Liczba wskazań na pedagogikę } & $\begin{array}{c}\text { Średni kapitał } \\
\text { ekonomiczny }\end{array}$ & $\begin{array}{c}\text { Średni kapitał } \\
\text { społeczny }\end{array}$ & $\begin{array}{c}\text { Średni kapitał } \\
\text { kulturowy }\end{array}$ & $\begin{array}{c}\text { Średni kapitał } \\
\text { symboliczny }\end{array}$ \\
\hline 1 wskazanie & 4,32 & 4,09 & 4,92 & 13,33 \\
\hline 2 wskazania & 4,26 & 4,09 & 5,13 & 13,48 \\
\hline 3 wskazania & 4,00 & 5,50 & 5,50 & 15,00 \\
\hline Średnia wśród „pedagogów” & 4,30 & 4,11 & 4,96 & 13,37 \\
\hline Średnia w całej populacji & 4,37 & 4,13 & 4,71 & 13,21 \\
\hline
\end{tabular}

Bardzo ciekawe dane ujawnia zestawienie w tabeli 8. Otóż przyszli pedagodzy mają wyższy kapitał symboliczny niż przeciętni kandydaci na studentów. Wprawdzie mają niższy kapitał ekonomiczny (pochodzą z uboższych rodzin, sami raczej mniej zarabiają albo nie zarabiają wcale) i nie mają wysokiego kapitału społecznego, ale „nadrabiają” kapitałem kulturowym. Są wyraźnie lepszymi uczniami, zdobywają nagrody, dyplomy, czytają sporo książek. Tendencja ta znajduje potwierdzenie w determinacji. Im ktoś bardziej chciał studiować pedagogikę, tym odznaczał się wyższym kapitałem symbolicznym - szczególnie kulturowym. Tak jak zastrzeżono na wstępie, bardzo ostrożnie należy traktować interpretacje wobec „potrójnie” zdeterminowanych.

\section{Badania nad studentami}

W tej części opracowania przedstawione zostaną w sposób zsyntetyzowany (Dejna, Nalaskowski 2013) dane ukazujące background studentów pedagogiki, będących u progu wejścia $\mathrm{w}$ rolę zawodową pedagoga oraz ich ścieżka dochodzenia do studiów pedagogicznych. Dla przypomnienia: badano studentów ostatniego roku studiów I stopnia.

\section{Ogólna charakterystyka studentów III roku pedagogiki}

Spośród badanych $31 \%$ pochodziło ze wsi, $26,5 \%$ z małych miast, jedynie $14 \%$ ze średnich miejscowości, a z największych miast 28,5\%. Dane dla ludności całego kraju wskazują, że ponad 38\% Polaków zamieszkuje obszary wiejskie - to znacznie mniej niż odsetek osób deklarujących tę właściwość w badaniu. 
ednocześnie dane demograficzne pokazuja, że jedynie 20\% ludności naszego kraju zamieszkuje największe miasta - zatem wśród próby badawczej „wielkomiejscy" ze swoimi ponad 28\% stanowią nadreprezentację (rocznik statystyczny GUS).

Podsumowując, można powiedzieć, że wśród studentów pedagogiki jest mniej osób pochodzących ze wsi i więcej z wielkich miast w porównaniu do danych populacji kraju.

Przeciętny student pedagogiki jest kobietą, dalej - studia podjął zaraz po maturze, choć jest też dość duże prawdopodobieństwo, że z pewnym opóźnieniem. Jest praktycznie identyczna szansa na to, że pochodzi ze wsi, małego, średniego czy dużego miasta.

\section{Rodzice: obecność, wykształcenie, zawód}

Rodzice tworzą jedną z kluczowych kategorii dla tego tekstu. Dzięki informacjom zgromadzonym w tej części możliwe jest ustalenie backgroundu wychowawczego badanych. W badanej próbie $11 \%$ osób zadeklarowało, że zostało wychowywanych tylko przez jednego rodzica. Co ciekawe, w tej grupy prawie $20 \%$ to dzieci samotnych ojców. Pewnym uzupełnieniem wiedzy o obecności rodziców przy wychowaniu była informacja o ich wykształceniu i zawodach, które wykonują.

$\mathrm{Na}$ podstawie uzyskanych wyników wykształcenie rodziców zostało przypisane do poszczególnych kategorii. Do najniższej grupy („Wykształcenie niskie") trafiali rodzice, którzy wspólnie legitymowali się wykształceniem zasadniczym lub podstawowym. Do kategorii „Wykształcenie średnie” trafiali rodzice, jeśli oboje posiadali wykształcenie średnie, lub jedno z nich miało wykształcenie średnie, a drugie zasadnicze lub podstawowe. Wreszcie do ostatniej grupy (,Wykształcenie wysokie”) trafiali rodzice, którzy posiadali wykształcenie wyższe lub jedno $z$ nich wyższe, a drugie średnie.

Należy stwierdzić, że rodzice studentów stanowią dość dobrze wykształconą grupę - szczególnie w odniesieniu do innych Polaków w podobnym wieku. Na tle populacji Polski grupa „Wykształcenie niskie” była mniej liczna (tu niecałe 22\%, w Polsce prawie 50\% - dane GUS). Występuje tu za to nadreprezentacja w kolejnych grupach. I tak kategoria „Wykształcenie średnie” w całej populacji kraju (w grupie wiekowej rodziców studentów - pokolenie 40-50 latków) szacowana jest na 34\%, a wśród badanych aż 52,8\%. Podobnie „Wykształcenie wysokie” - tu stanowi ponad 25\%, a w populacji całej Polski około $16 \%$. 
Podsumowując, można stwierdzić, że rodzice studentów pedagogiki legitymują się wyraźnie wyższym wykształceniem od swoich rówieśników.

Zawód rodziców respondentów analizowany był wyłącznie w dwóch kategoriach - wyższego i niższego prestiżu oraz niemożliwego do ustalenia. Należy podkreślić, że badanych pytano o to, jak zarabiają na życie ich rodzice, a nie w jakim kierunku się kształcili.

Przyporządkowanie do kategorii niższego i wyższego statusu następowało wg wcześniej ustalonych zasad. Do wyższego statusu przypisywane były np. wszystkie zawody cieszące się szczególnym zaufaniem społecznym (nauczyciel, lekarz, adwokat, urzędnik), zawody wymagające szczególnego wykształcenia i kwalifikacji (informatyk, księgowa), prywatni przedsiębiorcy, osoby piastujące stanowiska kierownicze. Analogicznie do niższej kategorii kwalifikowano m.in. osoby bezrobotne, osoby pracujące w zawodach niewymagających wysokich kwalifikacji (obsługa sklepu, pracownik mleczarni, kierowca), chłopi małorolni.

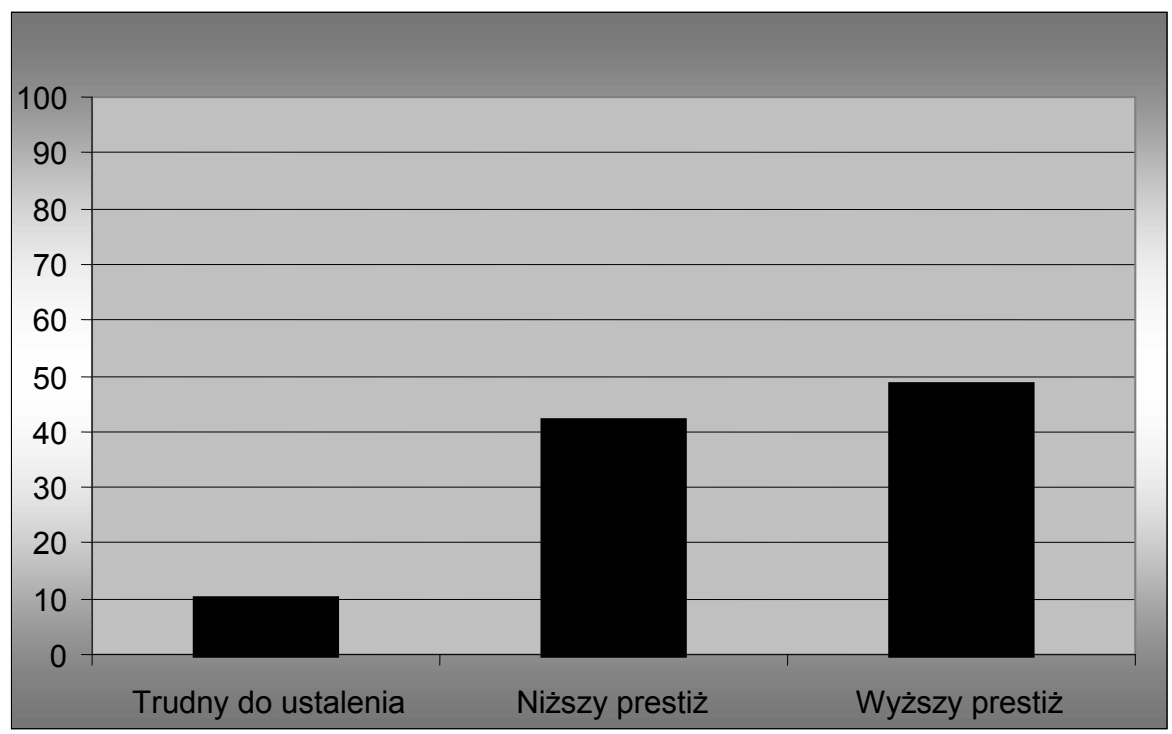

Wykres 1. Rodzice badanych - prestiż wykonywanego zawodu

Jak pokazuje zestawienie, rozkład w kategoriach prestiżu jest bliski symetrii. Niższy prestiż zawodu był domeną niecałych $42 \%$ badanych, o przeszło $6 \%$ więcej zakwalifikowanych zostało do wyższej grupy. Trudny do ustalenia prestiż ujawnił się jedynie wobec niecałych $10 \%$ badanych. 
Wyniki w tej kategorii zdają się przemawiać na korzyść środowiska rodzinnego badanych. Tylko 41,7\% rodzin wykazywało się niższym prestiżem. Realia rynku pracy są zgoła odmienne. Tu większość stanowisk, jak to pokazuje analiza struktury zatrudnienia, nie wymaga wyższych kwalifikacji (tylko nieco ponad 30\%), zatem należałoby mówić o dominacji niższej kategorii prestiżu na rynku pracy. Bezpieczna wydaje się konstatacja, że rodzice studentów pedagogiki w większości pracują w zawodach wyższego prestiżu społecznego, co odróżnia tę grupę od przeciętnej w populacji Polski.

Środowisko rodzinne młodych pedagogów tylko pod niektórymi względami znacząco odbiegało od innych polskich rodzin. Bardzo uogólniając, należy stwierdzić, że badani studenci pochodzili z tzw. dobrych domów. Zaobserwowano przeciętny odsetek rodzin niepełnych - w przeważającej liczbie wypadków oboje rodzice angażowali się w wychowanie potomstwa. Zawody wykonywane przez rodziców miały wyższy prestiż, niż wynikałoby to z danych ogólnopolskich. Częściej piastowali stanowiska kierownicze, prowadzili własną działalność gospodarczą, rzadziej byli bezrobotni. Prestiż ów nie przekładał się jednak na ocenę stanu materialnego domu, tu raczej dominowały oceny niższe. Rodziny miały duże tradycje edukacyjne. Wyraźnie wyższe od średniej było wykształcenie rodziców i rodzeństwa. To, co najwyraźniej odróżniało rodziny pedagogów od innych rodzin, to ich liczebność powodowana ponadprzeciętną liczbą rodzeństwa - w tym zakresie potwierdziła się potoczna opinia o dużej liczebności rodzin przyszłych pedagogów.

\section{Doświadczenia edukacyjne}

Ścieżka dociekań została podzielona na trzy części - odpowiadające jednocześnie trzem czasom. Przeszłość to czas szkoły średniej, informacje o typie, lokalizacji szkoły i zmaganiach z maturą. Teraźniejszość to „opowieść” o studiach - podejmowanych kierunkach, staraniach, wynikach. To także informacje o motywacjach i ocenie placówki. Przyszłość to w zasadzie wyłącznie pytanie o studia drugiego stopnia.

\section{Egzamin dojrzałości}

Rocznik 2005 był pierwszym zdającym obligatoryjnie maturę na nowych zasadach. Według nowych reguł egzamin maturalny miał być automatycznie przepustką na studia, stopniowo zastępując egzaminy wstępne. 
Zapytano respondentów, za którym razem udało się zdać egzamin dojrzałości. Co istotne, abiturienci rocznika 2005 nie byli tymi, których objęła wprowadzona wyjątkowo rok później ,,abolicja Giertycha”. Ówczesny minister oświaty, Roman Giertych, rozporządzeniem zmienił prawo, w myśl którego za egzamin zaliczony można było uznawać także ten, w którym ktoś nie spełnił warunków zaliczenia przedmiotu. Jedynym postawionym kryterium było uzyskanie średniej z całości minimum 30\%.

Tabela 9. Egzamin maturalny

\begin{tabular}{|l|c|}
\hline \multicolumn{1}{|c|}{ Liczba podejść do egzaminu maturalnego } & Udział w badanej próbie \\
\hline Zdany za pierwszym razem & $94,7 \%$ \\
\hline Zdany za drugim razem & $4,5 \%$ \\
\hline Brak odpowiedzi & $0,8 \%$ \\
\hline
\end{tabular}

Jeśli wziąć pod uwagę, że w opisywanej grupie dominowały osoby zdające egzamin w 2005 roku, to należy uznać wyniki matury przyszłych pedagogów za dobre. W skali kraju zdało wyraźnie mniej uczniów (86,5\%) (Dane z raportu Centralnej Komisji Egzaminacyjnej za 2005 r.), dlatego poziom zdawalności w próbie $(94,7 \%)$ należy uznać za wysoki.

\section{Rekrutacje}

Ważnym, ale złożonym w sensie analitycznym wątkiem był ten dotyczący kierunków, na które badani starali się dostać. Każdy z respondentów został poproszony o zaznaczenie, gdzie i na jaki kierunek próbował się dostać oraz z jakim skutkiem. Powodem bezpośredniego zainteresowania tym tematem było funkcjonujące potoczne przekonanie, że duża część studentów pedagogiki to osoby, którym nie udało się dostać na żaden inny kierunek. Ważne informacje dotyczące tej kwestii przynosi zestawienie liczby kierunków, na które - prócz tego na którym studiują - aplikowali.

Jak się okazuje, blisko $1 / 3$ respondentów nie szukała alternatywy, aplikując wyłącznie na pedagogikę na uczelni, na której właśnie studiuje. Nieco więcej, bo $35 \%$ badanych poszukiwało możliwości studiowania jeszcze w jednym miejscu, niecałe 24\% w dwóch innych miejscach. Na 3 i więcej innych kierunków/uczelni składało dokumenty mniej niż 10\% respondentów. Kluczowe dla oceny powołania i analizy motywacji studentów jest bliższe przyjrzenie się alternatywom, które badani sobie stwarzali w zakresie wybieranych studiów. 
Następnie przeglądowi poddano kierunki studiów, na które badani próbowali się dostać. Dla ułatwienia analizy podzielono je na dwie grupy: pokrewne i niepokrewne wobec pedagogiki. Do drugiej kategorii - kierunków niezwiązanych z pedagogiką - włączano wszystkie, które nie zostały ujęte w wykazie tych powiązanych - zatem zbiór ten był teoretycznie nieograniczony. Do pierwszej grupy włączano m.in.: pedagogikę (na innej uczelni), pedagogikę specjalną, pracę socjalna, psychologię, socjologię i filozofię.

Jak ilustruje zestawienie zaprezentowane w tabeli 10, wartości wskazuja, że tylko $2 / 3$ badanych było zdeterminowanych do studiowania pedagogiki lub podobnych jej kierunków. Druga część respondentów $(33,3 \%)$ gotowa była studiować coś zupełnie innego - to zaskakująco wysoki odsetek.

Tabela 10. Wybór kierunków pokrewnych względem pedagogiki

\begin{tabular}{|l|c|}
\hline \multicolumn{1}{|c|}{ Zainteresowanie kierunkami pokrewnymi pedagogice } & Udział w badanej próbie \\
\hline Tak & $66,7 \%$ \\
\hline Nie & $33,3 \%$ \\
\hline
\end{tabular}

Ciekawe informacje przynosi także ranking kierunków, na które badani najczęściej składali dokumenty.

Tabel 11. Ranking kierunków, na które aplikowali przyszli pedagodzy

\begin{tabular}{|l|c|}
\hline \multicolumn{1}{|c|}{ Kierunek } & Odsetek wskazań \\
\hline Pedagogika (na innej uczelni) & $44,6 \%$ \\
\hline Psychologia & $19,9 \%$ \\
\hline Filologia (różne) & $14,5 \%$ \\
\hline Socjologia & $9,0 \%$ \\
\hline Dziennikarstwo & $4,8 \%$ \\
\hline Biologia & $4,2 \%$ \\
\hline Ekonomia & $3,6 \%$ \\
\hline Administracja & $3,0 \%$ \\
\hline Kulturoznawstwo & $3,0 \%$ \\
\hline
\end{tabular}

$\mathrm{Z}$ zestawienia jasno wynika, że tylko niecała połowa badanych zabezpieczała się, aplikując na pedagogikę jeszcze gdzie indziej. Wartość ta i tak jest zawyżona, co ilustruje liczba wskazań, a nie osób, kiedy nierzadkim wypadkiem było, że respondenci podawali, iż próbowali się dostać jeszcze na dwie inne pedagogiki. Co to oznacza? Po pierwsze, możliwe, że wyraża się w ten sposób pewność dosta- 
nia się na pierwotnie zakładany kierunek. Skoro ktoś na pewno się dostanie, to po co się asekurować. Teoria ta znajduje zastosowanie wyłącznie wobec osób, które nie szukały alternatyw, one faktycznie aplikowały w jedno miejsce i im się udało. Wobec osób, które jednak składały dokumenty w wielu miejscach, należałoby powiedzieć, że nie były tak bardzo zainteresowane pedagogiką. Zatem jest więcej niż możliwe, że pedagogika była oferta, z której musieli skorzystać.

\section{Którędy do pedagogiki - wnioski i uogólnienia}

Przedstawione dane stanowią zaledwie wycinek szczegółowych raportów z szerokich i rozłożonych w czasie badań. Niemniej z wyselekcjonowanych i przedstawionych w tym tekście danych wyłania się interesujący obraz przyszłych pedagogów - planujących podjęcie studiów pedagogicznych oraz tych, którzy takie studia właśnie kończą. Obraz ten dotyczy niemal wyłącznie zaplecza młodych ludzi, korzeni leżących u podstaw ich edukacyjnych wyborów, kapitałów i ogólnej kondycji.

We wszystkich ukazanych zakresach ujawnia się ciekawa tendencja. Choć w uśrednieniu przyszli pedagodzy są dość przeciętni w odniesieniu do innych maturzystów, to widać, że im większą wykazują determinację do studiowania pedagogiki, tym są bardziej wartościowym narybkiem. Ci bardziej zdeterminowani odznaczają się wyższym kapitałem symbolicznym, szlachetniejszymi pobudkami do studiowania, częściej byli absolwentami LO oraz częściej swoje plany wiążą ze studiami stacjonarnymi i drugim stopniem. Całość uzupełniana jest o poczucie sprawstwa, które u bardziej zdeterminowanych jest wyraźnie wyższe. Co to wszystko oznacza? W największym skrócie można powiedzieć, że „rasowi” pedagodzy rekrutują się spośród wyraźnie ponadprzeciętnej młodzieży. Młodzieży o wysokim kapitale kulturowym, szlachetnych pobudkach do studiowania. To bardzo dobrzy i ambitni uczniowie. Idąc dalej tym tropem, można rzec, że ogólna przeciętność pedagogiki wynika z jej umasowienia, z tego, że dla olbrzymiej części studentów jest ona jedną z wielu przyjmowanych opcji.

Jak wykazały Badania nad studentami, dominującym typem szkoły, z którego rekrutowali się przyszli pedagodzy, okazało się liceum ogólnokształcące, do którego uczęszczało ponad $70 \%$ badanych, pozostałe części w zasadzie rozłożyły się równo: do technikum (14\%) i liceum profilowanego (13\%).

Respondenci okazali się niezłymi uczniami. Jedynie niecałe 5\% nie zdało matury przy pierwszym podejściu, a rozkład wyników egzaminów wykazuje znaczące przesunięcie w stronę ocen umiarkowanie dobrych i dobrych. Ponad $9 \%$ badanych ma na koncie już duże, akademickie porażki - przerwane stu- 
dia na innym kierunku. Jednocześnie prawie $2 \%$ badanych to osoby, które już ukończyły inny kierunek. Bez wątpienia można stwierdzić, że duża część badanych nie była specjalnie zdeterminowana do studiowania pedagogiki. Spośród respondentów $1 / 3$ nie podejmowała prób dostania się gdzieś indziej - nie asekurowała się. W grupie ubiegających się o przyjęcie do innej szkoły tylko połowa (44\%) startowała na pedagogikę.

Nie bez znaczenia jest też powszechna i bardzo popularna teza o tęsknocie pedagogów do psychologii. Około $20 \%$ osób w grupie próbującej dostać się gdzieś poza pedagogiką składało dokumety na psychologię - dostał się na nią tylko co trzeci badany. Podobna tęsknota ujawniła się w pytaniu, co najbardziej chcieli respondenci studiować - tu $20 \%$ z tych, którzy stwierdzili „,nie pedagogikę" - wybrało psychologię.

Zebrane dane każą też podejrzewać, że dla wielu osób pedagogika była „planem B”. Aż 73\% studentów nie dostało się na kierunki, na które aplikowała. Więcej niż $1 / 3$ badanych przyznaje, że nie chciała studiować pedagogiki. Ciekawe, że podobną rolę „ratunkową” odgrywały też socjologia, dziennikarstwo czy filologie. Respondenci często składali na nie dokumenty, ale nie deklarowali, że to je najbardziej chcieli studiować. Jednak l' badanych ujawniůo pozytywní motywacjć do studiowania pedagogiki, stawiajŕc na szlachetniejsze przesłanki.

Aż $82 \%$ badanych chce kontynuować na drugim stopniu studia pedagogiczne, to dużo, szczególnie że 5\% się jeszcze wahało.

Przedstawione dane kreślą ogólny profil przyszłych wychowawców. To wizerunek nie pozbawiony rys. Nade wszystko jednak można śmiało stwierdzić, że przyszli pedagodzy to wciąż awangarda wśród maturzystów planujących podjąć studia oraz wśród studentów innych kierunków.

\section{Bibliografia}

Dejna D., Nalaskowski F. (2013), Publiczni i niepubliczni. Przełom, Wydawnictwo Naukowe Uniwersytetu Mikołaja Kopernika, Toruń.

Dejna D., Nalaskowski F. (2013), Pedagogika jako kierunek studiów w świetle ostatnich raportów Polskiej Komisji Akredytacyjnej, Komitetu Ewaluacji Jednostek Naukowych oraz badań własnych, „Społeczeństwo i polityka”, nr 3, s. 52-64.

Kowalczuk-Walendziak M. (2012), Poczucie społecznego sprawstwa pedagogów. Studium teoretyczno-empiryczne, Oficyna Wydawnicza Impuls, Kraków.

Trutkowski C., Mandes S. (2005), Kapitat społeczny w małych miastach, Wydawnictwo Naukowe SCHOLAR, Warszawa. 